\title{
Detection of cell-mediated immunity to spermatozoa in mice and man by the leucocyte adherence-inhibition test
}

\author{
B. G. Dorsman, A. G. Tumboh-Oeri and T. K. Roberts \\ Department of Biological Sciences, University of Newcastle, New South Wales 2308, Australia
}

\begin{abstract}
Summary. A modification of the leucocyte adherence-inhibition test was developed to study cell-mediated immunity to spermatozoa. The test is highly reproducible and requires very low numbers of leucocytes. Deposition of spermatozoa in the genital tract of the female mouse by one normal mating is sufficient to sensitize the female to sperm antigens and the degree of sensitization is independent of the number of matings and the strain of male, and is not enhanced by subsequent pregnancy.
\end{abstract}

\section{Introduction}

The importance of cell-mediated immunity in immunoreproduction is unknown at present. Attempts to correlate cell-mediated immunity with infertility have yielded no conclusive results (Tyler, Tyler \& Denny, 1967; Mettler \& Schirwani, 1975), although sensitization of the cellular immune system in the female genital tract to paternal antigens is thought to play an important role in enhancing fetal survival (James, 1965; Beer \& Billingham, 1974; Palm, 1974). However, it is certain that the normal reproductive process in mammals results in the cellular immune system of the parous female being made sensitive to paternal antigens (Beer \& Billingham, 1976), as shown by an induction of tolerance to paternal grafts or as a heightened reactivity in in-vitro tests with maternal lymphocytes and paternal antigens. There have been very few experiments directed at defining the source of the paternal antigens which stimulate the mother (i.e. whether from the semen or the fetus). A fetal source is indicated in much of the literature (Beer \& Billingham, 1976), but some studies have clearly shown that the response was induced by the spermatozoa and not by fetal antigens (Prehn, 1960; Lengerova \& Vojtiskova, 1963; Beer \& Billingham, 1974).

Until now only two methods have been used for the estimation of cell-mediated immunity to sperm antigens in vitro: (a) the release of the lymphokine migration inhibition factor (MIF) from sensitized leucocytes following exposure to antigen, and (b) the blastic transformation of lymphocytes after cultivation with antigen (Rose, Hjort, Rumke, Harper \& Vyazov, 1976). Local cell-mediated immunity in the female genital tract against spermatozoa has been assayed in vivo by graft rejection and by enlargement of the para-aortic lymph nodes (Beer \& Billingham, 1974). Systemic sensitization has been measured in vivo by delayed hypersensitivity skin testing with spermatozoa (Marcus, Soffer Ben-David, Peleg \& Nebel, 1973).

The present study was undertaken to test the hypothesis that a cellular immune response to sperm antigens results after natural mating without subsequent pregnancy and to develop a rapid in-vitro method for the detection of the cellular response.

\section{Materials and Methods}

Mouse spermatozoa were collected by extrusion from the epididymides and vasa deferentia of mature males (Hoppe \& Pitts, 1973) and washed three times in Hanks balanced salt solution (calcium- and magnesium-free) by centrifugation at $1000 \mathrm{~g}$ for $5 \mathrm{~min}$. The spermatozoa were then suspended to the required concentration in Eagles Basal Medium (EBM: Commonwealth Serum Laboratories, Melbourne) containing $15 \%$ fetal calf serum (FCS: Commonwealth Serum Laboratories) and stored at $-20^{\circ} \mathrm{C}$. Before freezing, the number of leucocytes present in the sperm suspension was estimated with a haemocytometer. 
Human semen was collected by masturbation from a single fertile donor and prepared in the same way as for mouse spermatozoa.

The details of the various factors examined are given in the 'Results'. Pregnancy was prevented in mated mice by subcutaneous injection of 2 i.u. PMSG (Sigma, Los Angeles) within $48 \mathrm{~h}$ of finding a vaginal plug (Hoppe $\&$ Whitten, 1972). The presence of a vaginal plug was considered to represent one mating event.

Peripheral blood was collected, from the cubital vein in women and the retro-orbital plexus in mice, into heparin (30 i.u./ml blood) free of preservative. The blood was then diluted $1: 3(\mathrm{v} / \mathrm{v})$ in Hanks balanced salt solution. Centrifuge tubes were prepared with $3 \mathrm{ml}$ Ficoll-Hypaque of specific gravity 1.080 (9 g Ficoll (Pharmacia, Sydney), $20 \mathrm{ml} 85 \%$ (w/v) Hypaque (Winthrop Laboratories, Sydney) and $120 \mathrm{ml}$ distilled water) and overlayered with $7 \mathrm{ml}$ diluted blood. After centrifugation ( $30 \mathrm{~min}$, $500 \mathrm{~g}$ ) at room temperature, the leucocytes were harvested from the Hanks/Ficoll-Hypaque interface with a Pasteur pipette. The cells were diluted 1:5(v/v) in Hanks solution, washed twice and resuspended in EBM supplemented with $15 \%$ FCS.

Mouse peritoneal and splenic leucocytes were obtained as described by Ford \& Hunt (1973) and then washed as above. When preparations were contaminated by erythrocytes, an equal volume of $150 \mathrm{~mm}$-ammonium chloride was added before the first washing to lyse the erythrocytes.

\section{Test for leucocyte adherence-inhibition ( $L A I)$}

The LAI test (Halliday \& Miller, 1972) measures the capacity of sensitized lymphocytes to release, on contact with specific antigen, a lymphokine which inhibits the adherence of neighbouring leucocytes to glass or plastic surfaces. A microtest adaptation of the original method has been described by Holt, Roberts, Fimmel \& Keast (1975), and we have further modified the method. Briefly, $5 \mu \mathrm{l}$ of the leucocyte suspension (at a concentration of $1 \times 10^{6} \mathrm{cells} / \mathrm{ml}$ of EBM $+15 \% \mathrm{FCS}$ ) was dispensed into each well of a tissue-culture plate (No. 3034, Falcon Plastics, Sydney) followed by $5 \mu$ l antigen in EBM or of EBM alone. Cells and antigen suspensions were dispensed gently to prevent the leucocytes settling at the periphery of the well and thus affecting the accuracy of counting. The plates were incubated for $2 \mathrm{~h}$ at $37^{\circ} \mathrm{C}$, then inverted for $15 \mathrm{~min}$ at room temperature to allow non-adherent cells to float off the bottom of the wells. The plates were then slowly flooded with Hanks solution which was poured off again immediately, and next flooded with methanol and fixed for 5-6 min. Plates can be kept at this stage for up to 3 days at $4^{\circ} \mathrm{C}$. Before counting, the plates were stained with Giemsa. The mean number of adherent cells in each well were counted at $\times 100$ in 10 random fields viewed through an eyepiece containing an opaque disc with a $2-\mathrm{mm}$ hole. The inhibition of adherence was calculated from the formula:

$$
\left(1-\frac{\text { Mean number of cells in wells with antigen }}{\text { Mean number of cells in control wells }}\right) \times 100
$$

\section{Test for leucocyte migration-inhibition factor (MIF)}

The test used was basically that of Bendixen \& Soborg (1969), developed for the detection of cellular hypersensitivity in man, with modifications. The chambers used were similar to those described by Rajapakse \& Glynn (1975). A rubber ring of outer diameter $26 \mathrm{~mm}$ and inner diameter 21 $\mathrm{mm}$ was obtained by cutting a hole in a Macartney bottle-top washer and fixed onto a microscope slide $(75 \times 25 \mathrm{~mm})$ with Araldite (Ciba-Geigy Plastics, U.K.). After drying and hardening at room temperature for $72 \mathrm{~h}$ or in an automatic air dryer at $50^{\circ} \mathrm{C}$ for $24 \mathrm{~h}$, the slides were washed once in detergent, 3 times in tap water, 3 times in deionized water and 3 times in distilled water, air dried and autoclaved for $20 \mathrm{~min}$ at $114^{\circ} \mathrm{C}, 1.013 \times 10^{5} \mathrm{~N} / \mathrm{m}^{-2}$. Coverslips were made by cutting microscope slides, washed as for the chambers, into two equal parts. Capillary tube sealing compound was prepared by heating equal weights of paraffin wax and petroleum jelly together and the molten compound was poured onto a flat square metal holder and kept at $4^{\circ} \mathrm{C}$ until used.

The spleen leucocyte suspension was transferred into $10 \mu \mathrm{l}$ capillary tubes (Solandra Scientific, Sydney) with a $10 \mu$ l Hamilton syringe. One end of each tube was then sealed with the capillary tube 
sealing compound to a length of $2 \mathrm{~mm}$. The tubes were centrifuged in batches of 15 at $200 \mathrm{~g}$ for $30 \mathrm{~min}$, cut at the EBM-cell interface with a diamond pencil and mounted, 3 tubes to a chamber, onto the floor of a culture chamber with silicone grease. The chambers were filled with EBM only or with the sperm suspensions at various concentrations. The chambers were covered, sealed with silicone grease, and incubated at $37^{\circ} \mathrm{C}$ for $18 \mathrm{~h}$. During the incubation period the cells migrate from the cut end of the capillary and form a plaque on the floor of the incubation chamber. The migration outlines of the cells from each tube were enlarged with an overhead projector and copied onto tracing paper; the areas were calculated as the product of the width and height of the tracing relative to the cut end of the capillary. Inhibition of more than $20 \%$ was considered significant because leucocytes from virgin mice always gave values $<20 \%$.

Each experiment was carried out with leucocytes from 3 mice and migration inhibition indices were calculated from the formula:

$$
\frac{\text { Mean area of migrations in test chambers }}{\text { Mean area of migrations in control chambers }} \times 100
$$

\section{Statistical analysis}

The statistical significance of the results was assessed by applying Student's $t$ tests to cell counts of wells with and without antigen (see Tables 1, 2 and 5). Analysis of variance was performed on 15 replicates to test for reproducibility.

\section{Results}

\section{LAI test: mouse}

Standardization. A standard curve was produced by testing leucocytes from 3 people with known sensitivities to tuberculin. The results of increasing concentrations of tuberculin (purified protein derivative: Commonwealth Serum Laboratories) are shown in Table 1, and the test was clearly able to discriminate between sensitized and non-sensitized leucocytes at antigen concentrations greater than 0.5 i.u. $/ \mathrm{ml}$.

Table 1. Leucocyte adherence-inhibition values obtained with human peripheral leucocytes and tuberculin as the antigen

\begin{tabular}{lrrrcc}
\hline & \multicolumn{5}{c}{ Tuberculin PPD conc. (i.u./ml) } \\
\cline { 2 - 6 } \multicolumn{1}{c}{$\begin{array}{l}\text { Skin test } \\
\text { response }\end{array}$} & 0.5 & 1 & 2 & 10 & 20 \\
\hline Positive & $5^{*}$ & $20^{* *}$ & $46^{* *}$ & $69^{* *}$ & $84^{* *}$ \\
Inconclusive & -1 & -1 & -2 & $23^{* *}$ & $52^{* *}$ \\
Negative & -3 & 1 & -5 & -4 & -6 \\
\hline
\end{tabular}

$* P \leqslant 0.05$ (Student's $t$ test).

** $P \leqslant 0.01$ (Student's $t$ test).

Site of leucocyte collection. To determine the optimum site of collection of leucocytes for the LAI test, peripheral, splenic and peritoneal leucocytes were collected from 1 virgin and 1 mated female mouse $(\mathrm{C} 57 \mathrm{BL} / \mathrm{J})$ and tested with spermatozoa from $\mathrm{C} 57 \mathrm{BL} / \mathrm{J}$ males. With increasing amounts of antigen, peripheral leucocytes from the virgin female were unaffected in their ability to adhere to plastic, but peritoneal and to a lesser extent splenic leucocytes became more adherent with increasing sperm concentrations (Table 2). Tests with peripheral and peritoneal leucocytes from the female which had been mated 7 times with C57 males over a period of 100 days gave increased LAI values with increasing amounts of antigen (Table 2). 
Table 2. Leucocyte adherence-inhibition values obtained with leucocytes from C57 female mice ( 1 virgin and 1 mated) and C57 spermatozoa as antigen

\begin{tabular}{lcccccc}
\hline & \multicolumn{5}{c}{ Sperm conc. $\left(\times 10^{-4} / \mathrm{ml}\right)$} \\
\cline { 2 - 7 } Leucocytes & Mouse & $1 \cdot 25$ & $2 \cdot 5$ & 5 & 10 & 20 \\
\hline Peripheral & Virgin & 0 & $-2 \cdot 5^{*}$ & $5 \cdot 0^{* *}$ & $-0 \cdot 7$ & $-4 \cdot 5^{*}$ \\
Peritoneal & Virgin & $-1 \cdot 5^{*}$ & $-19 \cdot 2^{* *}$ & $-34 \cdot 4^{* *}$ & $-51 \cdot 1^{* *}$ & $-43 \cdot 4^{* *}$ \\
Splenic & Virgin & 0 & $-0 \cdot 2$ & $-9 \cdot 1^{* *}$ & $-12 \cdot 5^{* *}$ & $-20 \cdot 6^{* *}$ \\
Peripheral & Mated $\times 7$ & $1 \cdot 5$ & $28 \cdot 1^{* *}$ & $41 \cdot 2^{* *}$ & $51 \cdot 9^{* *}$ & $69 \cdot 9^{* *}$ \\
Peritoneal & Mated $\times 7$ & $-12 \cdot 9^{*}$ & $-6 \cdot 6^{* *}$ & $-2 \cdot 1$ & $-3 \cdot 1$ & $15 \cdot 5^{* *}$ \\
\hline \multicolumn{6}{c}{$* P \leqslant 0.05$ (Student's $t$ test). } \\
$* * 0.01$ (Student's $t$ test).
\end{tabular}

Effect of genotype and coital frequency. Peripheral leucocytes were obtained from female mice of the $\mathrm{A} / \mathrm{J}$ or $\mathrm{C} 57 \mathrm{BL} / \mathrm{J}$ strain. Three mice were tested for each treatment. The females were mated once, 4 times or 7 times to an A-strain or C57-strain male and killed at least 7 days after the last mating. The sperm antigen used in the test was from a male of the same strain that had been used for the mating. In all mated females the LAI response was very similar regardless of the genotype of the stud male and the frequency of mating (Table 3). No significant inhibition was obtained with virgin mice.

Table 3. Leucocyte adherence-inhibition values (mean \pm s.e.m.) obtained with peripheral leucocytes from female mice (3/group) and mouse spermatozoa as the antigen

\begin{tabular}{|c|c|c|c|c|c|c|c|}
\hline \multicolumn{2}{|c|}{ Mouse strain } & \multirow{2}{*}{$\begin{array}{c}\text { Reproductive } \\
\text { state } \\
\text { of female }\end{array}$} & \multicolumn{5}{|c|}{ Sperm conc. $\left(\times 10^{-4} / \mathrm{ml}\right)$} \\
\hline Male & Female & & 1.25 & 2.5 & 5 & 10 & 20 \\
\hline $57 \mathrm{BL}$ & $\mathrm{C} 57 \mathrm{BL}$ & $\begin{array}{l}\text { Virgin } \\
\text { Virgin }+ \text { PMSG } \\
\text { Mated } \times 1 \\
\text { Mated } \times 4 \\
\text { Mated } \times 7 \\
\text { Litters } \times 2\end{array}$ & $\begin{array}{r}-0.5 \pm 0.5 \\
-0.9 \pm 1.2 \\
-1.2 \pm 0.5 \\
1.7 \pm 0.5 \\
4.8 \pm 3.3 \\
6.8 \pm 1.7\end{array}$ & $\begin{array}{r}-1 \cdot 1 \pm 0 \cdot 7 \\
-0 \cdot 1 \pm 0.9 \\
8 \cdot 0 \pm 3 \cdot 6 \\
19 \cdot 1 \pm 5 \cdot 3 \\
18 \cdot 5 \pm 4 \cdot 8 \\
20 \cdot 1 \pm 1 \cdot 7\end{array}$ & $\begin{array}{r}3 \cdot 1 \pm 1 \cdot 0 \\
0.2 \pm 0.4 \\
21 \cdot 0 \pm 7 \cdot 5 \\
35.5 \pm 7.0 \\
31.4 \pm 4.9 \\
32.3 \pm 1.4\end{array}$ & $\begin{array}{r}0.5 \pm 0.3 \\
-1 \cdot 1 \pm 0.3 \\
44 \cdot 2 \pm 6 \cdot 5 \\
53 \cdot 3 \pm 5 \cdot 7 \\
44 \cdot 3 \pm 4 \cdot 2 \\
55 \cdot 1 \pm 1 \cdot 8\end{array}$ & $\begin{array}{r}-0.4 \pm 1.9 \\
1.9 \pm 2.0 \\
63.1 \pm 4.9 \\
62.3 \pm 5.7 \\
63.6 \pm 3.2 \\
71.4 \pm 1.0\end{array}$ \\
\hline A & A & $\begin{array}{l}\text { Virgin } \\
\text { Virgin }+ \text { PMSG } \\
\text { Mated } \times 1 \\
\text { Mated } \times 4 \\
\text { Litters } \times 2\end{array}$ & $\begin{array}{r}-0.3 \pm 1.4 \\
-0.6 \pm 0.4 \\
6.5 \pm 1 \cdot 4 \\
4.8 \pm 2.2 \\
6.5 \pm 2.1\end{array}$ & $\begin{array}{r}0.7 \pm 1.6 \\
-0.3 \pm 0.3 \\
8.7 \pm 2.9 \\
11.8 \pm 3 \cdot 1 \\
16.9 \pm 1.8\end{array}$ & $\begin{array}{l}0.2 \pm 0.4 \\
-0.4 \pm 0.5 \\
25 \cdot 5 \pm 7 \cdot 1 \\
31 \cdot 4 \pm 10 \cdot 7 \\
33 \cdot 4 \pm 2 \cdot 3\end{array}$ & $\begin{array}{c}1 \cdot 1 \pm 0 \cdot 8 \\
-1 \cdot 2 \pm 0 \cdot 6 \\
58 \cdot 7 \pm 13 \cdot 3 \\
39 \cdot 7 \pm 9 \cdot 5 \\
52 \cdot 3 \pm 2 \cdot 3\end{array}$ & $\begin{array}{c}3 \cdot 9 \pm 2 \cdot 7 \\
6 \cdot 9 \pm 2 \cdot 1 \\
72 \cdot 2 \pm 6 \cdot 9 \\
47 \cdot 0 \pm 10 \cdot 7 \\
71 \cdot 1 \pm 2 \cdot 1\end{array}$ \\
\hline A & $\mathrm{C} 57 \mathrm{BL}$ & $\begin{array}{l}\text { Virgin } \\
\text { Virgin }+ \text { PMSG } \\
\text { Mated } \times 1 \\
\text { Mated } \times 4\end{array}$ & $\begin{array}{r}0.5 \pm 0.3 \\
-0 \cdot 1 \pm 0.2 \\
7 \cdot 1 \pm 0 \cdot 8 \\
5 \cdot 5 \pm 1 \cdot 2\end{array}$ & $\begin{array}{r}-1.0 \pm 1.4 \\
-0.2 \pm 0.4 \\
15 \cdot 3 \pm 1 \cdot 6 \\
9.4 \pm 0.2\end{array}$ & $\begin{array}{r}0.6 \pm 1.2 \\
0.3 \pm 0.3 \\
22 \cdot 3 \pm 1 \cdot 1 \\
15.8 \pm 1 \cdot 2\end{array}$ & $\begin{array}{r}0.1 \pm 0.5 \\
0.8 \pm 0.3 \\
27.9 \pm 1.7 \\
37.0 \pm 1.2\end{array}$ & $\begin{array}{r}-0.6 \pm 0.7 \\
2.7 \pm 0.8 \\
44.8 \pm 2 \cdot 1 \\
56.6 \pm 2.5\end{array}$ \\
\hline C57BL & A & $\begin{array}{l}\text { Virgin } \\
\text { Virgin }+ \text { PMSG } \\
\text { Mated } \times 1 \\
\text { Mated } \times 4\end{array}$ & $\begin{array}{r}-1 \cdot 7 \pm 1 \cdot 1 \\
-1 \cdot 1 \pm 0 \cdot 6 \\
23 \cdot 4 \pm 5 \cdot 6 \\
8 \cdot 0 \pm 2 \cdot 7\end{array}$ & $\begin{array}{r}-1 \cdot 6 \pm 1 \cdot 6 \\
-0.8 \pm 0.5 \\
31 \cdot 2 \pm 2 \cdot 8 \\
15 \cdot 4 \pm 6.3\end{array}$ & $\begin{array}{r}-0.5 \pm 0.9 \\
-0.8 \pm 0 \cdot 8 \\
41 \cdot 2 \pm 5 \cdot 1 \\
30 \cdot 0 \pm 2 \cdot 4\end{array}$ & $\begin{array}{l}-0.9 \pm 1.4 \\
-0.6 \pm 0 \cdot 1 \\
64 \cdot 5 \pm 4 \cdot 0 \\
45 \cdot 0 \pm 10 \cdot 2\end{array}$ & $\begin{array}{r}0.2 \pm 0.5 \\
4.1 \pm 1.3 \\
73.3 \pm 4.5 \\
60.9 \pm 7.8\end{array}$ \\
\hline
\end{tabular}

\section{LAI test: man}

Leucocytes were collected from 21 volunteers classified into three equal groups according to their sexual history: Group 1, virgin; Group 2, non-virgin nulliparous and using various forms of contraception; Group 3, parous. All leucocytes were tested against a single antigen preparation made from semen of a single fertile donor. As shown in Table 4 nearly all the women who had had contact with seminal antigens had significant LAI values, whereas none of the virgins had a significant reaction to spermatozoa. 
Table 4. Leucocyte adherence-inhibition values obtained with human peripheral leucocytes and human spermatozoa as antigen at a concentration of $2 \times 10^{5} / \mathrm{ml}$

\begin{tabular}{|c|c|c|}
\hline \multirow[b]{2}{*}{ Group } & \multicolumn{2}{|l|}{ LAI values } \\
\hline & Individual values & Mean \pm s.e.m. \\
\hline $\begin{array}{l}\text { 1, Virgin } \\
\text { 2, Nulliparous but inseminated } \\
\text { 3, Parous }\end{array}$ & $\begin{array}{r}-10 \cdot 1,-5 \cdot 7,-5 \cdot 4,-4 \cdot 9,-4 \cdot 8,-4 \cdot 5,-2 \cdot 9 \\
-1 \cdot 5,20 \cdot 6,21 \cdot 5,27 \cdot 1,27 \cdot 2,27 \cdot 7,28 \cdot 8 \\
-4 \cdot 1,17 \cdot 0,23 \cdot 6,30 \cdot 3,31 \cdot 1,33 \cdot 0,41 \cdot 0\end{array}$ & $\begin{array}{r}-5 \cdot 5 \pm 0.9 \\
25 \cdot 7 \pm 1 \cdot 3 \\
30 \cdot 4 \pm 3 \cdot 2\end{array}$ \\
\hline
\end{tabular}

\section{MIF test}

Effect of coital frequency. Splenic leucocytes were obtained from female mice of the A strain which were mated once or 5 times with A-strain males. Three mice were used in each test. The sperm antigen was also from an A-strain male. Sensitization was apparent after only one mating and there was no significant difference between the two groups of mated mice (Table 5).

Table 5. Migration-inhibition factor indices obtained with splenic leucocytes from A-strain female mice and A-strain spermatozoa as antigen

\begin{tabular}{|c|c|c|c|c|c|c|}
\hline \multirow{2}{*}{$\begin{array}{c}\text { Reproductive } \\
\text { state } \\
\text { of females }\end{array}$} & \multicolumn{6}{|c|}{ Sperm conc. $\left(\times 10^{-6} / \mathrm{ml}\right)$} \\
\hline & 0.5 & 1 & 2 & 5 & 10 & 20 \\
\hline Virgin & 一 & $100 \cdot 2$ & $99 \cdot 3$ & $116 \cdot 7^{*}$ & $99 \cdot 3$ & 97.9 \\
\hline Mated once & —† & $56 \cdot 8^{* *}$ & $64 \cdot 8 * *$ & $43 \cdot 7^{* *}$ & $35 \cdot 8 * *$ & $24 \cdot 18^{* *}$ \\
\hline Mated $\times 5$ & $76 \cdot 2^{*}$ & $75 \cdot 3^{*}$ & $65 \cdot 1^{*}$ & $60 \cdot 3^{*}$ & $46 \cdot 7^{*}$ & $34 \cdot 9 * *$ \\
\hline
\end{tabular}

\section{Discussion}

The present results clearly show that the leucocyte adherence-inhibition (LAI) test of Halliday \& Miller (1972), as modified by Holt et al. (1975), can be applied to studies of immunoreproduction. That this test measures cell-mediated immunity has been shown by comparisons with migrationinhibition factor (MIF) assays and cutaneous delayed-type hypersensitivity reactions (Holt et al., 1975). However, the LAI test has the advantage over these other tests in that it requires the use of only very small numbers of cells: the MIF assay and the lymphocyte transformation test (Rose et al., 1976) require about $2 \times 10^{7}$ cells and $1 \times 10^{6}$ cells respectively per test, whereas the present modification of the LAI test requires only about $5 \times 10^{3}$ cells per test.

Our results with mice showed that leucocytes from virgins could always be distinguished from those of non-virgin females. We cannot at present explain the observation that splenic and peritoneal leucocytes from virgins became more adherent in the presence of increasing amounts of antigen. However, there was no significant increase in the degree of sensitization with increasing coital frequency, indicating that one insemination is sufficient to sensitize the female.

Cellular sensitization of the female to sperm antigens following natural mating indicates that spermatozoa are inherently antigenic and are able to activate the cellular immune system after natural deposition in the female genital tract. Spermatozoa are known to carry various antigens (Beer \& Billingham, 1976) which may be sperm-specific, male-specific or species-specific, but there has been little study of the induction of immunity to spermatozoa after mating. Prehn (1960) showed that mice 
mated to sterile males of the same strain partly abrogated their ability to reject male skin grafts. Matings of mice in which pregnancy had been prevented by ligation of the oviducts (Lengerova \& Vojtiskova, 1963) also resulted in the mated females becoming partly tolerant to male skin isografts. In-vitro studies of this phenomenon are rare. Mettler \& Schirwani (1975) found that more than $70 \%$ of a group of sterile women studied showed sensitization to spermatozoa, as detected by the MIF assay, but the possibility that sensitization could have resulted from immunization of the mother by paternal antigens on fetal tissue was not excluded.

The antigens on the spermatozoa which induce the sensitization detected by our modified LAI test have not yet been defined. Major histocompatibility antigens may be excluded because sensitization can be demonstrated after intra-strain matings, but it is not yet possible to distinguish between malespecific and sperm-specific antigens.

Clarke \& Kirby (1966) suggested that some kind of immunological interaction between females and their histo-incompatible fetuses might favour the survival of such offspring and thus help to maintain the complex histocompatibility polymorphisms found in mammals. This postulate has been supported by several studies (James, 1967; Hull, 1969; Palm, 1974; Beer, Scott \& Billingham, 1975). It is generally considered that the antigens which induce the beneficial immune reaction in the mother are derived from fetal tissue, but we propose that the antigens on spermatozoa deposited at one insemination can provide the primary stimulus via the uterus and thus prepare the mother for the ensuing implantation of the developing blastocyst.

We thank Heidi Saxarra and D. J. Kay for help during the preparation of this work, and the A.R.G.C. and the Ford Foundation for financial assistance.

\section{References}

BeER, A.E. \& Billingham, R.E. (1974) Host responses to intrauterine tissue, cellular and foetal allografts. $J$. Reprod. Fert., Suppl. 21, 59-88.

BeER, A.E. \& Billingham, R.E. (1976) The Immunobiology of Mammalian Reproduction. Prentice-Hall, Englewood Cliffs.

Beer, A.E., Scott, J.R. \& Billingham, R.E. (1975) Histoincompatibility and maternal immunological status as determinants of fetoplacental weight and litter size in rodents. $J$. exp. Med. 142, 180-196.

Bendixen, G. \& Soborg, M. (1969) A leucocyte migration technique for in-vitro detection of cellular (delayed type) hypersensitivity in man. Dan. Med. Bull. 16, 1-6.

Clarke, B. \& KirbY, D.R.S. (1966) Maintenance of histocompatibility polymorphisms. Nature, Lond. 211, 999-1000.

FORD, W.L. \& HuNT, S.V. (1973) The preparation and labelling of lymphocytes. In Handbook of Experimental Immunology, 2nd edn, pp. 23.1-23.27. Ed. D. M. Weir. Blackwell Scientific Publications, Oxford.

Halliday, W.J. \& Miller, S. (1972) Leucocyte adherence inhibition: a simple test for cell-mediated tumour immunity and serum blocking factors. Int. J. Cancer 9, 477-483.

Holt, P.G., Roberts, L.M., Fimmel, P.J. \& Keast, D. (1975) The LAI microtest, a rapid and sensitive procedure for the demonstration of cell-mediated immunity in vitro. J. Immun. Methods 8, 277-288.

HopPE, P.C. \& PITTS, S. (1973) Fertilization in vitro and development of mouse ova. Biol. Reprod. 8, 420426
Hoppe, P.C. \& Whitten, W.K. (1972) Pregnancy block: imitation by administered gonadotropin. Biol. Reprod. 7, 254-259.

Hull, P. (1969) Maternal-fetal incompatibility associated with the H-3 locus in the mouse. Heredity 24, 203-209.

JAMES, D.A. (1965) Effects of antigenic dissimilarity between mother and foetus on placental size in mice. Nature, Lond. 205, 613-614.

JAMES, D.A. (1967) Some effects of immunological factors on gestation in mice. J. Reprod. Fert. 14, 265275.

Lengerova, A. \& Vojtiskova, M. (1963) Prolonged survival of syngeneic male skin grafts in parous C57BL mice. Folia biol., Praha 9, 72-73.

Marcus, Z.H., Soffer, Y., Ben-David, A., Peleg, S. \& Nebel, L. (1973) Studies on sperm antigenicity. 1. Delayed hypersensitivity to spermatozoa. Eur. $J$. Immunol. 3, 75-78.

Mettler, L. \& Schirwani, D. (1975) Macrophage migration inhibitory factor in female sterility. $A m . J$. Obstet. Gynec. 121, 117-120.

PALM, J. (1974) Maternal-fetal histoincompatibility in rats: an escape from adversity. Cancer Res. 34, 20612065.

PrehN, R.T. (1960) Specific homograft tolerance induced by successive matings and implications concerning choriocarcinoma. J. natn. Cancer Inst. 25, 883-886.

Rajapakse, D.A. \& GlynN, L.E. (1975) A simplified chamber suitable for the capillary macrophage migration inhibition test and other similar tissue culture work. J. Immun. Methods 8, 195-198. 
Rose, N.R., HJort, T., RUmke, P., HaRper, M.J.K. \& Vyazov, O. (1976) Techniques for detection of isoand auto-antibodies to human spermatozoa. Clin. exp. Immunol. 23, 175-199.
Tyler, A., Truer, E.T. \& Denny, P.C. (1967) Concepts and experiments in immunoreproduction. Fert. Steril. 18, 153-166. 